\title{
sciendo
}

\section{Repositioning sales as an influence on innovation and a source of sustainable competitive advantage}

\author{
Ovidiu-Iulian BUNEA \\ The Bucharest University of Economic Studies, Bucharest, Romania \\ Ovidiu.Bunea@Man.Ase.Ro
}

\begin{abstract}
The main purpose of this paper was to analyze the relationship between the company's sales activity, innovation and competitive advantage using a representative sample of firms analyzed in dynamics in 2014-2018 time period. Scientific literature on the determinants of innovation has shown that large firms are more likely to innovate when compared to small firms and that innovation inputs significantly increase innovation output. The types of innovation to which this work refers are process, product, organizational and marketing innovation. Thus, looking at the history and evolution of companies, in terms of financial statement and, more specifically, sales, we can reveal relevant information about their innovation activities and potential sustainable competitive advantage emerging from innovation. Sales can be considered input into the innovation process through the information gathered from customers, thus contributing to the innovation process. For example, when it comes to launching a new product or improving the existing one, sales feedback could be of great help because the salesperson has the ability to collect important customer feedback such as: what are the issues with the present product, what could be improved and how etc. So, we ask: Does sales contribute to the innovation process and gaining sustainable competitive advantage? If so, what happens with the degree of innovation according to the volume of sales, the size of the company, the number of employees? To highlight the relationship between sales, innovation and competitive advantage, and to estimate the predictability of the model, multiple linear regression was used. Thus, the analysis has shown that sales activity positively and significantly influences innovation when it comes to the information that sales can make available, contributing in some cases as a source of sustainable competitive advantage. Research also identified a significant but negative influence between sales, innovation and sustainable competitive advantage when we talk about sales in terms of their volume.
\end{abstract}

Keywords: Innovation, Competitive Advantage, Sales, Innovation Determinants, Process Innovation, Product Innovation.

\section{Introduction}

A new type of economy was born with the emergence of influences from the business and customer environment, such as giving more importance to knowledge, creativity and innovative services. This new economic paradigm involves creating value for the client through intangible resources such as knowledge, unique organizational structures, innovation, creativity, brand, rather than through tangible resources (Kamasak, 2015). Of course, these changes have taken place due to the pressure of competition, which has led firms to adopt innovative and creative ways to gain and sustain a competitive edge in their markets, and this is now evident in most industries. Increasingly, specialists (Clark \& Guy, 1998; Ambec et al., 2013; Erkkilä \& Piironen, 2018; Harwiki et al., 2018) state that innovation is a particularly important element for companies in order to ensure long-term survival and a good place in the market. With this outlined context, there is a need to identify as many determinants of innovation as necessary to obtain competitive advantage. 
The novelty of this approach was to establish a relationship between the data in the firm's financial statement and data collected from surveys conducted by the Romanian National Institute of Statistics (2018), which were based on the Community Innovation Survey (CIS), launched by Eurostat. Also, by merging these data, research has succeeded in identifying the relationships that are created between sales, seen as innovation input and innovation output seen as process and product innovation, which was another novelty of the approach presented in this paper.

The main hypothesis from which the study started was that there are significant and positive relationships between the chosen variables. Research variables were: sales volume, employees, process innovation, product innovation, cooperation for innovation and innovation expenses. A multiple linear regression model was applied in three ways, using as dependent variable, sales volume, then product innovation, then process innovation, all the remaining variables being used as independent variables. The model was applied to see what kind of relationships appear between the variables chosen and also to see if sales have a good influence on innovation. The results indicated a significant but negative relationship between sales and process innovation as well as a significant and positive relationship between sales and product innovation. The results may throw a shadow on the value of sales feedback on product innovation.

\section{Literature review}

It is not a mystery that, increasingly, both firms and countries face the threat or opportunity (for some) of global competition (Corbos, 2011), which implies an increased strategic dynamic (Carstea et al., 2017). Developing new products, increasing production capacities, identifying and attacking new markets, value chain efficiency, are just a few of the strategies used to gain and sustain a competitive edge. Thus, innovation is becoming more and more present in company's strategies due to its obvious contribution to the competitive advantage and becomes a way to go for many companies. Thus, we note the importance of innovation management, which is still an important subject for researchers (Afuah and Afuah, 2003; Trott, 2008; Adams et al., 2006; Tidd and Bessant, 2018; Frishammar et al., 2018) as well as for companies and countries.

In the current context, innovation usually involves a large investment, but it brings a number of benefits, such as cost savings, new products that better meet customer needs, creating or adapting innovative processes, quality after-sales services (Cârstea et al., 2002), or new marketing techniques (Popescu et al., 2017; Popescu et al., 2018; Bunea, 2018). No matter where innovation takes place, be it product, process, marketing, or organizational innovation, today's businesses will need to be innovative to compete better on their market at one time. We can consider innovation as a continual change in the company's processes, products and services that face fierce competition and need to identify or create differentiated competitive advantages based on the development of their own key competencies in conditions of increased rivalry between competitors (Zehir et al., 2015). Again, competition is triggering a certain degree of innovation, as it has been noted that less innovative firms are facing a decline in market share. Thus, in the competitive struggle, companies try to differentiate themselves by implementing different strategies, whether they choose to become the best innovators or the most cost-effective and so on. Some companies manage to achieve such goals by using internal and external factors that they possess. To be 
innovative, a firm will have to put together various skills, capabilities, resources and knowledge (Fagerberg, 2018).

Going on various theories, (Arrow, 1962; Porter, 1985) that a company operating in a competitive industry faces more incentives to innovate by investing in research and development than a firm operating in a monopolistic industry, we can say that innovation is an important source of competitive advantage. Literature provides us with a wide range of factors to demonstrate that they have an influence on a company's innovation activity. These factors include firm size factors, and implicit issues related to available resources, but also strategic elements such as membership of a particular group or a particular focus on international markets, barriers to obtaining funding for innovation, the level of rivalry between competitors in the industry, the economic conditions in the country / region in which they operate, and so on. It seems that there are so many variables that influence different components of innovation, and by selecting or omitting some of them, the results of empirical research are influenced.

A study on business innovation determinants (Zemplinerová and Hromádková, 2012) concluded that innovation input influences positively and significantly innovation output, and the relationship is growing stronger as the size of the firm grows. However, innovation output is shrinking for large firms, which may mean that they are less efficient in converting input into output.

Another study (Lee, 2004), conducted on the determinants of innovation in the Malaysian manufacturing sector, showed a negative relationship between export sales and the likelihood of innovation. Baldwin and Sabourin (2002) had shown that for small and medium-sized companies in Canada, an indicator of success, which results in better performance for the firm translated through growth, profitability and productivity, is closely linked to the degree of emphasis that firms place on innovation. Also, another study (Baldwin and Johnson, 1999) used a sample of new firms to show that their performance depends on innovation. The presence of innovation in firms increases productivity (Crépon et al., 1998). Other papers (Ulusoy et al., 2010) have considered types of innovation such as product, process, marketing and organizational. This study revealed that the most powerful determinant of innovation was intellectual capital, followed by organizational culture.

The Community Innovation Survey, launched by Eurostat, has been a widely used database and an important resource for researchers who have successfully used it to identify the links between possible determinants of innovation, i.e. the relationship between innovation input and innovation output. Thus, at the level of the countries of the European Union, researchers analyzed the relationship between innovation input and innovation output, such as Lööf et al. (2004) for Sweden and Germany, or Lehtoranta (2005) for Finland. The overall results of these and other studies (Griffith et al., 2006; Masso and Vahter, 2008; Damijan et al., 2011; Vakhitova and Pavlenko, 2010; Hashi and Stojcic, 2010; Halpern and Muraközy, 2012) highlighted a positive relationship between innovation input and innovation output as well as the positive effect innovation output had on the performance of the firm.

\section{Research sample}

The representative research sample contained 429 innovative firms about which I collected the data with which I built the variables of the research to test the theoretical model. I 
collected data on these companies using the platform provided by the Ministry of Public Finance of Romania for the financial indicators. Also, with the help of the platform provided by the National Institute of Statistics in Romania, I collected data on innovative companies. Research on innovation carried out by the National Institute of Statistics in Romania was based on the Community Innovation Survey (CIS) of the European Union. All collected data were analyzed using IBM SPSS 20.

PICBE $\mid 495$

The sample I used was a representative one because I used a well-established method for determining the size of the sample. Different methods can be used to determine the sample size, as the literature suggests (Chow et al., 2017; Shieh, 2018; Machin et al., 2018; Kotrlik and Higgins, 2001; Dupont and Plummer, 1990; Weinberg and Kleinman, 2003; Dell et al., 2002; Boddy, 2016; Singh and Masuku, 2014), all depending on the research theme and the specificity of each research process. For this particular research I used a method involving determining the research sample based on statistical tables proposed by Krejcie and Morgan (1970). The statistical tables proposed by the two previously mentioned authors were sources of information for determining the size of the sample. The tables can be used to study 10 to $1,000,000$ observation units, and the values presented in them were based on the following formula:

$$
s=\frac{X^{2} N P(1-P)}{d^{2}(N-1)}+X^{2} P(1-P)
$$

Where:

$\mathrm{s}$ - sample size;

$X^{2}$ - theoretical value of the chi-square test for a degree of freedom and a statistical significance level of 0,05 ;

$\mathrm{N}$ - investigated group size;

$\mathrm{P}$ - parameter that expresses a specific share of the population;

$d^{2}$ - degree of accuracy.

According to data provided by the National Institute of Statistics in Romania, the total number of innovative enterprises was approximately 28,800. Taking this into account, according to Krejcie and Morgan's statistical tables, a representative sample for this research would be 379 observation units. The research sample used contained 429 observation units, which meant, according to the established criteria, that it was representative of the companies categorized as innovative in Romania.

The evolution of innovative enterprises by types of innovators for 2014, 2016 and 2018 was synthesized in Figure 1. We note that globally successful innovative enterprises had an upward trend, and the level of innovators who have not finished or abandoned their activities tends to decline. I also chose to base this research on process and product innovators as they have a larger share in the total of innovative businesses. 


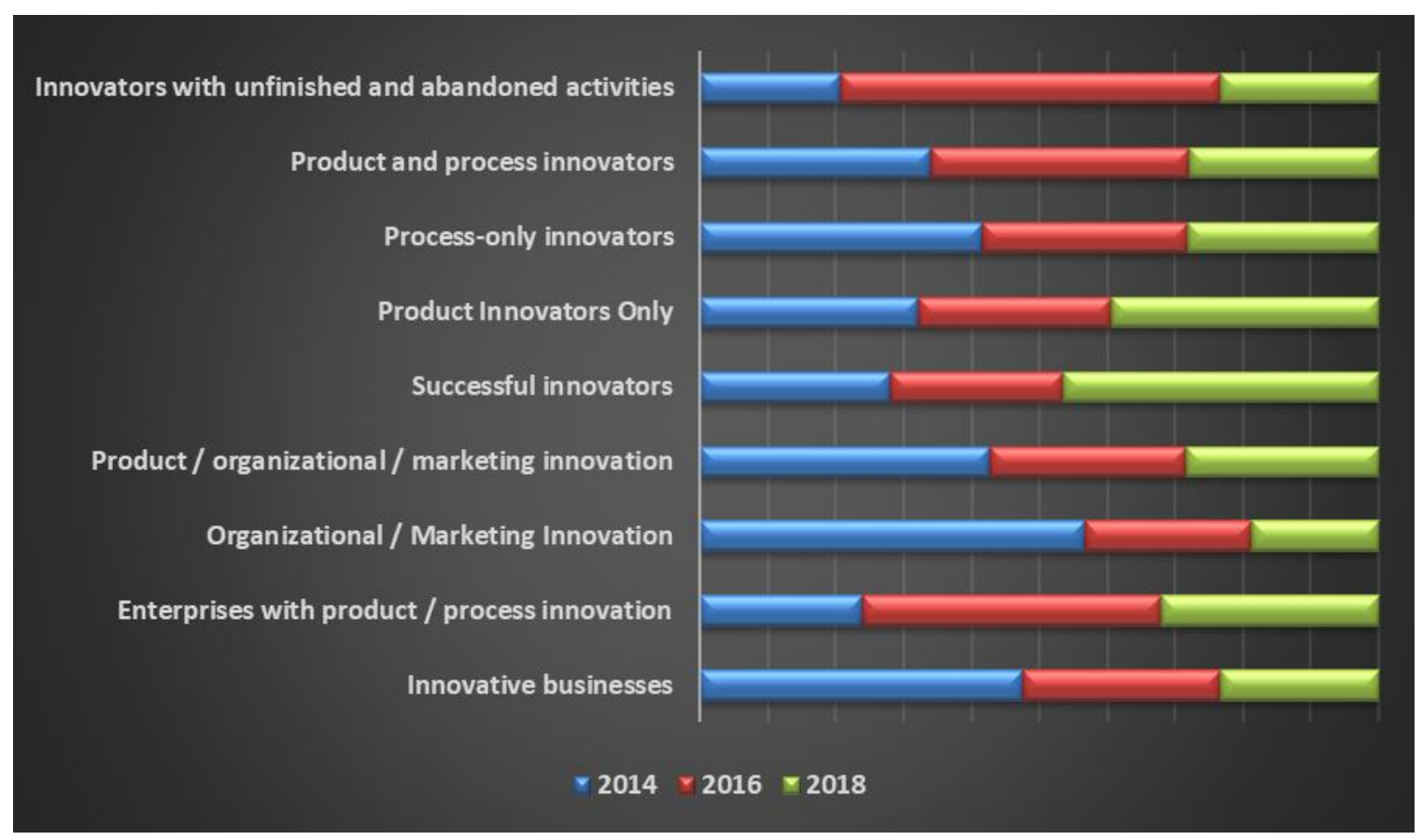

Figure 1. Evolution of innovative enterprises by types of innovators

Source: Authors' own research

\section{Methodology}

Four hundred and twenty-nine innovative companies were analyzed using the following variables: sales volume, number of employees, innovation cooperation, innovation expenses, product innovation and process innovation. The descriptive statistics of the variables are shown in Table 1. It is important to note here that I used logarithmic values, since the initial values of the variables were not normally distributed.

Table 1. Descriptive Statistics of the research variables

\begin{tabular}{|c|c|c|c|c|c|c|c|c|c|}
\hline & $\mathbf{N}$ & $\mathbf{R}$ & Min & Max & $\mathbf{M}$ & SD & $\mathbf{V}$ & Skewness & Kurtosis \\
\hline Sales volume & 429 & 2,24 & $\overline{6,41}$ & 8,65 & 2,31 & 0,54 & 0,30 & $-0,322$ & $-0,512$ \\
\hline Employees & 429 & 1,90 & 4,14 & 6,04 & 2,10 & 0,51 & 0,27 & $-0,66$ & $-1,006$ \\
\hline $\begin{array}{l}\text { Product } \\
\text { innovation }\end{array}$ & 429 & 1,42 & $-0,27$ & 1,15 & 2,73 & 0,36 & 0,13 & 0,308 & $-0,441$ \\
\hline $\begin{array}{c}\text { Process } \\
\text { innovation }\end{array}$ & 429 & 1,26 & $-0,13$ & 1,12 & 7,30 & 0,34 & 0,11 & 0,090 & $-0,597$ \\
\hline $\begin{array}{l}\text { Cooperation } \\
\text { for innovation }\end{array}$ & 429 & 1,03 & 5,19 & 0,61 & 1,63 & 0,24 & 0,24 & $-0,179$ & 0,559 \\
\hline $\begin{array}{l}\text { Innovation } \\
\text { expenses }\end{array}$ & 429 & 2,70 & $-26,65$ & $-0,70$ & 2 & 0,74 & 0,56 & $-0,650$ & $-0,365$ \\
\hline $\begin{array}{l}\text { Valid N } \\
\text { (listwise) }\end{array}$ & 429 & & & & & & & & \\
\hline
\end{tabular}

Source: Authors' own research

To see what kind of relationships were born between the variables of research and how powerful those relationships were, Pearson's data analysis was performed revealing the correlations synthesized in Table 2. 
Table 2. Results for Pearson`s $r$ data analysis

\begin{tabular}{|c|c|c|c|c|c|c|c|c|}
\hline & & $\begin{array}{c}\text { Sales } \\
\text { volume }\end{array}$ & Employees & $\begin{array}{c}\text { Product } \\
\text { innovation }\end{array}$ & $\begin{array}{c}\text { Process } \\
\text { innovation }\end{array}$ & $\begin{array}{c}\text { Cooperation } \\
\text { for } \\
\text { innovation } \\
\end{array}$ & $\begin{array}{c}\text { Innovation } \\
\text { expenses }\end{array}$ & \\
\hline \multirow{3}{*}{ Sales volume } & $\begin{array}{l}\text { Pearson } \\
\text { Correlation }\end{array}$ & 1 & $.760^{* *}$ & .134 & .116 & $.448^{*}$ & $.500^{* *}$ & PICBE | 497 \\
\hline & Sig. (2-tailed) & & .000 & .006 & .028 & .010 & .004 & \\
\hline & $\mathrm{N}$ & 429 & 429 & 429 & 429 & 429 & 429 & \\
\hline \multirow{3}{*}{ Employees } & $\begin{array}{l}\text { Pearson } \\
\text { Correlation }\end{array}$ & $.760^{* *}$ & 1 & $.400^{*}$ & $.423^{*}$ & .288 & .233 & \\
\hline & Sig. (2-tailed) & .000 & & .023 & .016 & .110 & .200 & \\
\hline & $\mathrm{N}$ & 429 & 429 & 429 & 429 & 429 & 429 & \\
\hline \multirow{3}{*}{$\begin{array}{l}\text { Product } \\
\text { innovation }\end{array}$} & $\begin{array}{l}\text { Pearson } \\
\text { Correlation }\end{array}$ & .134 & $.400^{*}$ & 1 & $.880^{* *}$ & .043 & -.158 & \\
\hline & Sig. (2-tailed) & .006 & .023 & & .000 & .814 & .387 & \\
\hline & $\mathrm{N}$ & 429 & 429 & 429 & 429 & 429 & 429 & \\
\hline \multirow{3}{*}{$\begin{array}{l}\text { Process } \\
\text { innovation }\end{array}$} & $\begin{array}{l}\text { Pearson } \\
\text { Correlation }\end{array}$ & .116 & $.423^{*}$ & $.880^{* *}$ & 1 & .112 & -.164 & \\
\hline & Sig. (2-tailed) & .028 & .016 & .000 & & .542 & .368 & \\
\hline & $\mathrm{N}$ & 429 & 429 & 429 & 429 & 429 & 429 & \\
\hline \multirow{3}{*}{$\begin{array}{l}\text { Cooperation } \\
\text { for } \\
\text { innovation }\end{array}$} & $\begin{array}{l}\text { Pearson } \\
\text { Correlation }\end{array}$ & $.448^{*}$ & .288 & .043 & .112 & 1 & .189 & \\
\hline & Sig. (2-tailed) & .010 & .110 & .814 & .542 & & .300 & \\
\hline & $\mathrm{N}$ & 429 & 429 & 429 & 429 & 429 & 429 & \\
\hline \multirow{3}{*}{$\begin{array}{l}\text { Innovation } \\
\text { expenses }\end{array}$} & $\begin{array}{l}\text { Pearson } \\
\text { Correlation }\end{array}$ & $.500^{* *}$ & .233 & -.158 & -.164 & .189 & 1 & \\
\hline & Sig. (2-tailed) & .004 & .200 & .387 & .368 & .300 & & \\
\hline & $\mathrm{N}$ & 429 & 429 & 429 & 429 & 429 & 429 & \\
\hline
\end{tabular}

**. Correlation is significant at the 0.01 level (2-tailed).

*. Correlation is significant at the 0.05 level (2-tailed).

Source: Authors' own research

Before conducting the multiple linear regression, the assumption of a normal distribution of data was tested and it was determined that the assumption was satisfied considering that all the data of the variable distributions were associated with a less than 2.0 skewness and a less than 9.0 kurtosis - see Table 1 (Schmider et al., 2010; Mardia, 1970; Kim, 2013).

To further test the assumption of normal distribution of data, the Shapiro-Wilk test of normality was applied resulting a p value greater than .05 (Shapiro and Wilk, 1965; Razali and Wah, 2011; Ghasemi and Zahediasl, 2012). Considering that the null hypothesis for this test was that the data was not statistically significant different from a normal distribution, the Shapiro-Wilk p values (see Table 3) indicated that we have failed in rejecting the null hypothesis, therefore it can be assumed once again that the data had a normal distribution. 
Table 3. Shapiro-Wilk test of Normality

\begin{tabular}{lccc}
\hline \hline Variable & $\begin{array}{c}\text { Shapiro-Wilk } \\
\text { Statistic }\end{array}$ & df & Sig. \\
& & & \\
\hline Sales volume & .975 & 429 & .637 \\
Employees & .967 & 429 & .430 \\
Product innovation & .970 & 429 & .508 \\
Process innovation & .955 & 429 & .204 \\
$\begin{array}{l}\text { Cooperation for } \\
\text { innovation }\end{array}$ & .967 & 429 & .425 \\
Innovation expenses & .928 & 429 & .136 \\
\hline \hline \multicolumn{3}{c}{ Source: Authors' own research }
\end{tabular}

A multiple linear regression was conducted in order to examine how well the research variables could predict the evolution of process innovation, product innovation, or sales volume. For this, the same regression model was used in three hypostases, changing only the dependent variable from one case to another. As we can already observe in Table 2, some of the variables were statistically significant correlated with each other. The three regression equations, each corresponding with a certain dependent variable were the following:

$$
\begin{aligned}
& \begin{aligned}
\stackrel{\wedge}{\text { Process inn. }} & =\beta(i . v .1) * i . v .1+\beta(i . v .2) * i . v .2+\beta(i . v .3) * i . v .3+\beta(i . v .4) * \text { i.v. } 4 \\
& +\beta(\text { i.v.5)*i.v.5-Constant }
\end{aligned} \\
& \begin{aligned}
\stackrel{\wedge}{\text { Productinn. }} & =\beta(i . v .1) * i . v .1+\beta(i . v .2) * i . v .2+\beta(i . v .3) * i . v .3+\beta(i . v .4) \\
& * \text { i.v. } 4+\beta(i . v .5) * i . v .5-\text { Constant }
\end{aligned}
\end{aligned}
$$

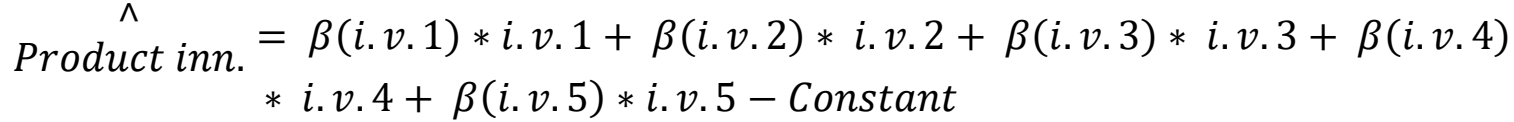

$$
\begin{aligned}
& \stackrel{\wedge}{\text { Sales volume }}=\beta(i . v .1) * i . v .1+\beta(i . v .2) * i . v .2+\beta(i . v .3) * i . v .3+\beta(i . v .4) \\
& \text { *i.v. } 4+\beta(i . v .5) * i . v .5-\text { Constant }
\end{aligned}
$$

Where:

Process inn. $=$ Estimated Process Innovation

Product inn. $=$ Estimated Product Innovation

Sales volume $=$ Estimated Sales Volume

$\beta=$ Unstandardized regression coefficient

i.v.1 = independent variable 1

i.v. 2 = independent variable 2

i.v. 3 = independent variable 3

i.v. $4=$ independent variable 4

i.v. 5 = independent variable 5 


\section{Data analysis and empirical results}

The results presented in Table 4 showed that the Adjusted R Square for the equation was .762 which indicated that $76.2 \%$ of the variance in Process Innovation was predictable from Sales Volume, Employees, Product Innovation, Cooperation for Innovation and Innovation Expenses. According to Cohen (1992) this was a strong relationship.

Going further, the work highlighted the results only for those independent variables that had statistically significant $\mathrm{p}$ values. Thus, the bootstrapped $95 \%$ confidence interval for the slope to predict Process Innovation ranged from -.350 to .082 (Sales Volume) and 0.569 to 0.961 (Product Innovation). Thus, for each one unit increase in Sales Volume, Process Innovation decreases by about -.350 to .082 points and for each one unit increase in Product Innovation, Process Innovation increases by about 0.569 to 0.961 points.

Further, we could observe that the F-test was statistically significant with a $5 \%$ level of significance. That indicated the fact that as a whole, the independent variables justified the variation on Process Innovation.

Table 4. Results of the Multiple Linear Regression with process innovation as dependent variable

\begin{tabular}{|c|c|c|c|c|c|}
\hline Variables & $\begin{array}{l}\text { Estimated } \\
\text { Coefficient }\end{array}$ & $\begin{array}{c}\text { Standard } \\
\text { Robust } \\
\text { Error } \\
\end{array}$ & VIF & $\begin{array}{c}P \\
\text { value }\end{array}$ & $\begin{array}{c}\text { Level of } \\
\text { Significance }\end{array}$ \\
\hline Sales volume & -1.34 & .105 & 3.77 & .013 & $* *$ \\
\hline Employees & .152 & .101 & 3.13 & .145 & $* *$ \\
\hline Product innovation & .765 & .095 & 1.33 & .000 & $* * *$ \\
\hline Cooperation for innovation & .153 & .141 & 1.27 & .286 & $* * *$ \\
\hline Innovation expenses & -.001 & .049 & 1.48 & .984 & $* * *$ \\
\hline Constant & .211 & .476 & & .007 & $* *$ \\
\hline $\begin{array}{l}* * *=\mathrm{th} \\
* *=\mathrm{th}\end{array}$ & $\begin{array}{r}\text { F-test }(5,424) \\
\text { Adjusted } \\
\text { coefficient ha } \\
\text { coefficient had }\end{array}$ & $\begin{array}{l}29 \\
0.798(.000 \\
\text { luare }=.762 \\
1 \% \text { level of } \\
5 \% \text { level of }\end{array}$ & Snifica & & \\
\hline
\end{tabular}

Source: Authors' own research

The results presented in Table 5 showed that the Adjusted R Square for the equation was .742 which indicated that $74.2 \%$ of the variance in Product Innovation was predictable from Sales Volume, Employees, Process Innovation, Cooperation for Innovation and Innovation Expenses. According to Cohen (1992) this was a strong relationship.

Further, the analysis highlighted as before, the results only for those independent variables that had statistically significant $p$ values. Thus, the bootstrapped $95 \%$ confidence interval for the slope to predict Product Innovation ranged from -.172 to .316 (Sales Volume) and 0.692 to 1.169 (Process Innovation). Thus, for each one unit increase in Sales Volume, Product Innovation decreases by about -.172 to .316 points and for each one unit increase in Process Innovation, Product Innovation increases by about 0.692 to 1.169 points.

Further, we could observe that the F-test was statistically significant with a 5\% level of significance. That indicated the fact that as a whole, the independent variables justifyed the variation on Product Innovation. 
Table 5. Results of the Multiple Linear Regression with product innovation as dependent variable

\begin{tabular}{cccccc}
\hline \hline Variables & $\begin{array}{c}\text { Estimated } \\
\text { Coefficient }\end{array}$ & $\begin{array}{c}\text { Standard } \\
\text { Robust } \\
\text { Error }\end{array}$ & VIF & $\begin{array}{c}\text { P } \\
\text { value }\end{array}$ & $\begin{array}{c}\text { Level of } \\
\text { Significance }\end{array}$ \\
\hline \hline Sales volume & .072 & .119 & 3.95 & .049 & $* *$ \\
Employees & -.012 & .116 & 3.40 & .916 & $* *$ \\
Process innovation & .931 & .116 & 1.44 & .000 & $* * *$ \\
Cooperation for innovation & -.136 & .157 & 1.29 & .392 & $* * *$ \\
Innovation expenses & -.023 & .053 & 1.47 & .670 & $* * *$ \\
Constant & -.317 & .523 & & .009 & \\
& F-test (5, 424) $=18.832(.000) * *$ & & \\
& Adjusted R Square $=.742$ \\
& $* * *=$ the coefficient had a 1\% level of significance & & \\
& $* *=$ the coefficient had a 5\% level of significance & & \\
\hline \hline
\end{tabular}

PICBE $\mid 500$

Source: Authors' own research

The results presented in Table 6 showed that the Adjusted R Square for the equation was .702 which indicated that $70.2 \%$ of the variance in Sales Volume was predictable from Product Innovation, Employees, Process Innovation, Cooperation for Innovation and Innovation Expenses. According to Cohen (1992) this was a strong relationship.

Further, we were able to see the results only for those independent variables that had statistically significant $\mathrm{p}$ values. Thus, the bootstrapped $95 \%$ confidence interval for the slope to predict Sales Volume ranged from -.463 to .851 (Product Innovation); from .479 to .992 (Employees); from 0.015 to 1.005 (Cooperation for Innovation) and 0.039 to 0.363 (Innovation Expenses). Thus, for each one unit increase in Product Innovation, Sales Volume decreases by about -.463 to .851 points; for each one unit increase in Employees, Sales Volume increases by about 0.479 to 0.992 points; for each one unit increase in Cooperation for Innovation, Sales Volume increases by about 0.015 to 1.005 points and for each one unit increase in Innovation Expenses, Sales Volume increases by about 0.039 to 0.363 points.

Going further with the analysis, we could observe that the F-test was statistically significant with a $5 \%$ level of significance, which indicated the fact that as a whole, the independent variables justified the variation in Sales Volume.

Table 6. Results of the Multiple Linear Regression with sales volume as dependent variable

\begin{tabular}{|c|c|c|c|c|c|}
\hline Variables & $\begin{array}{l}\text { Estimated } \\
\text { Coefficient }\end{array}$ & $\begin{array}{c}\text { Standard } \\
\text { Robust } \\
\text { Error } \\
\end{array}$ & VIF & $\begin{array}{c}P \\
\text { value }\end{array}$ & $\begin{array}{c}\text { Level of } \\
\text { Significance }\end{array}$ \\
\hline Product innovation & .194 & .320 & 4.55 & .049 & $* *$ \\
\hline Employees & .736 & .125 & 1.46 & .000 & $* *$ \\
\hline Process innovation & -.439 & .345 & 4.70 & .213 & $* * *$ \\
\hline Cooperation for innovation & .510 & .241 & 1.13 & .044 & $* * *$ \\
\hline Innovation expenses & .201 & .079 & 1.18 & .017 & $* * *$ \\
\hline Constant & 3.260 & .583 & & .000 & $* *$ \\
\hline $\begin{array}{c}* * *=\text { th } \\
* *=\text { the }\end{array}$ & $\begin{array}{r}\mathrm{N} \\
\text { F-test }(5,424) \\
\text { Adjusted } \\
\text { coefficient ha } \\
\text { coefficient had }\end{array}$ & $\begin{array}{l}29 \\
15.637(.00 \\
\text { unare }=.702 \\
1 \% \text { level of } \\
5 \% \text { level of }\end{array}$ & nifica & & \\
\hline
\end{tabular}

Source: Authors' own research 


\section{Conclusions}

In this research, I analyzed the influence of sales as well as other variables viewed as an influence on innovation and as a source of competitive advantage by using a multiple linear regression model. The model was applied three times, using for each case a different dependent variable. Thus, the regression analysis results using process innovation as dependent variable, asserts that sales volume (significant and negative relationship) and product innovation (significant and positive relationship) can describe changes that would appear in process innovation, with the mention that product innovation had a greater influence on process innovation. This result may indicate that high volume sales do not lead to an innovative process, and further, an innovative product can be an important source of process innovation. Going further, the regression analysis results using product innovation as dependent variable, asserts that sales volume (significant and positive relationship) and process innovation (significant and positive relationship) can describe changes that would appear in product innovation, with the mention that process innovation had a greater influence on product innovation. This result could indicate that a sales surplus could be due to an innovative product, and that there is a positive and reciprocal relationship between the two elements. Also, the same results indicated that the presence of an innovative process can result in an innovative product.

The results for the third regression analysis using sales volume as dependent variable, asserts that product innovation, employees, cooperation for innovation and innovation expenses were all variables that could describe changes that would appear in sales volume, all having a significant and positive influence, with the mention that employees and cooperation for innovation were two independent variables which had a greater influence on sales volume compared to the other used variables. This result would indicate that sales volume increases when an innovative product is sold. Also, firms with an upward trend in innovation co-operation, number of employees and innovation spending are more successful in sales.

Overall, the results of this research confirmed previous research (Zemplinerová and Hromádková, 2012; Griffith et al., 2006; Masso and Vahter, 2008; Damijan et al., 2011; Vakhitova and Pavlenko, 2010; Hashi and Stojcic, 2010; Halpern and Muraközy, 2012) in the sense that there is a positive and significant relationship between innovation input and innovation output. The results may have important implications for the competition policy to allow companies to cooperate more for innovation. Although innovation expenses do not appear to directly influence the degree of innovation, they still have a positive and significant relationship with sales and therefore innovation subsidies should be maintained as incentives.

The main limitation of this paper is that other variables for the linear regression model have not been considered. It would have been interesting to see if the predictive power of the model remained as high when adding other variables for innovation input, and especially if the variable that characterized the sales would have influenced innovation output at least as significant, but we can consider this limitation as a future research question.

\section{References}

Adams, R., Bessant, J., \& Phelps, R. (2006). Innovation management measurement: A review. International journal of management reviews, 8(1), 21-47. 
Afuah, A., \& Afuah, A. (2003). Innovation management: strategies, implementation and profits. Oxford University Press: New York.

Ambec, S., Cohen, M. A., Elgie, S., \& Lanoie, P. (2013). The Porter hypothesis at 20: can environmental regulation enhance innovation and competitiveness? Review of environmental economics and policy, 7(1), 2-22.

Arrow, K. J. (1962). The economic implications of learning by doing. The review of economic studies, 29(3), 155-173.

Baldwin, J. R., \& Johnson, J. (1999). Entry, innovation and firm growth. In Are small firms important? Their role and impact (pp. 51-77). Springer, Boston, MA.

Baldwin, J. R., \& Sabourin, D. (2002). Advanced technology use and firm performance in Canadian manufacturing in the 1990s. Industrial and Corporate Change, 11(4), 761789.

Boddy, C. R. (2016). Sample size for qualitative research. Qualitative Market Research: An International Journal, 19(4), 426-432.

Bunea, O.I., Corboș, R.A., Popescu, R.I., Todircan, M. (2018). The Importance of Promotion Policy in Increasing the Competitiveness of Cultural Organizations in Romania. Case Study: The National Museum of Natural History „Grigore Antipa”. In Proceedings of the 31st International Business Information Management Association Conference Innovation Management and Education Excellence through Vision 2020. (Vol. 1, No. 11, pp. 372-384).

Carstea, G., Corbos, R. A., Popescu, R. I., \& Bunea, O. I. (2017). ANALYSIS OF THE INFLUENCE OF SOME INDICATORS ON THE PROFITABILITY OF THE FMCG RETAIL MARKET IN ROMANIA. In Proceedings of the INTERNATIONAL MANAGEMENT CONFERENCE (Vol. 11, No. 1, pp. 481-492). Faculty of Management, Academy of Economic Studies, Bucharest, Romania.

Cârstea, G., Deac, V. Popa, I. \& Podgoreanu, S. (2002). Analiza strategică a mediului concurenţial. Editura Economică: București.

Chow, S. C., Shao, J., Wang, H., \& Lokhnygina, Y. (2017). Sample size calculations in clinical research. Chapman and Hall/CRC.

Clark, J., \& Guy, K. (1998). Innovation and competitiveness: a review: Practitioners' forum. Technology Analysis \& Strategic Management, 10(3), 363-395.

Cohen, J. (1992). A power primer. Psychological bulletin, 112(1), 155.

Corbos, R. A. (2011). Integration and Competition-Appropriate Approaches for Achieving Excellence in Management. Business Excellence and Management, 1(1), 67-73.

Crépon, B., Duguet, E., \& Mairessec, J. (1998). Research, Innovation And Productivity: An Econometric Analysis At The Firm Level. Economics of Innovation and new Technology, 7(2), 115-158.

Damijan, J. P., Kostevc, Č., \& Rojec, M. (2011). Innovation and firms' productivity growth in Slovenia: Sensitivity of results to sectoral heterogeneity and to estimation method. In Innovation, Growth and Competitiveness (pp. 165-193). Springer, Berlin, Heidelberg.

Dell, R. B., Holleran, S., \& Ramakrishnan, R. (2002). Sample size determination. ILAR journal, 43(4), 207-213.

Dupont, W. D., \& Plummer Jr, W. D. (1990). Power and sample size calculations: a review and computer program. Controlled clinical trials, 11(2), 116-128. 
Erkkilä, T., \& Piironen, O. (2018). Rankings and Global Knowledge Governance: Higher Education, Innovation and Competitiveness. Springer.

Fagerberg, J. (2018). Mobilizing innovation for sustainability transitions: A comment on transformative innovation policy. Research Policy, 47(9), 1568-1576.

Frishammar, J., Richtnér, A., Brattström, A., Magnusson, M., \& Björk, J. (2018). Opportunities and challenges in the new innovation landscape: Implications for innovation auditing and innovation management. European Management Journal.

Ghasemi, A., \& Zahediasl, S. (2012). Normality tests for statistical analysis: a guide for nonstatisticians. International journal of endocrinology and metabolism, 10(2), 486.

Griffith, R., Huergo, E., Mairesse, J., \& Peters, B. (2006). Innovation and productivity across four European countries. Oxford review of economic policy, 22(4), 483-498.

Halpern, L., \& Muraközy, B. (2012). Innovation, productivity and exports: the case of Hungary. Economics of Innovation and New Technology, 21(2), 151-173.

Harwiki, W., Choiron, A., \& Hartini, S. (2018). BATIK CREATIVE INDUSTRY: CREATIVITY, INNOVATION AND COMPETITIVENESS TO ENCOUNTER GLOBAL MARKET. JBFEM, $1(2), 189-196$.

Hashi, I., \& Stojcic, N. (2010). The Impact of Innovation Activities on Firm Performance Using a Multi (Stage Model: Evidence from the Community Innovation Survey 4. (Working Paper No. 410/2010). Network Studies and Analyses. Warsaw.

Kamasak, R. (2015). Determinants of innovation performance: a resource-based study. Procedia-Social and Behavioral Sciences, 195, 1330-1337.

Kim, H. Y. (2013). Statistical notes for clinical researchers: assessing normal distribution (2) using skewness and kurtosis. Restorative dentistry \& endodontics, 38(1), 52-54.

Kotrlik, J. W. K. J. W., \& Higgins, C. C. H. C. C. (2001). Organizational research: Determining appropriate sample size in survey research appropriate sample size in survey research. Information technology, learning, and performance journal, 19(1), 43.

Krejcie, R. V., \& Morgan, D. W. (1970). Determining sample size for research activities. Educational and psychological measurement, 30(3), 607-610.

Lee, C. (2004). The determinants of innovation in the Malaysian manufacturing sector: an econometric analysis at the firm level. ASEAN Economic Bulletin, 21(3), 319-329.

Lehtoranta, O. (2005). Determinants of Innovation and the Economic Growth of Innovators. Tracing the evolution of innovative firms over time.

Lööf, H., Peters, B., \& Janz, N. (2004). Innovation and productivity in German and Swedish manufacturing firms: Is there a common story?. Problems \& perspectives in management, 2, 184-204.

Machin, D., Campbell, M. J., Tan, S. B., \& Tan, S. H. (2018). Sample Sizes for Clinical, Laboratory and Epidemiology Studies. John Wiley \& Sons.

Mardia, K. V. (1970). Measures of multivariate skewness and kurtosis with applications. Biometrika, 57(3), 519-530.

Masso, J., \& Vahter, P. (2008). Technological innovation and productivity in late-transition Estonia: econometric evidence from innovation surveys. The European Journal of Development Research, 20(2), 240-261.

Popescu, R. I., Corboş, R. A., \& Bunea, O. I. (2018). STUDY ON THE PERCEPTION OF YOUNG ROMANIANS ON THE ECO-MARKETING AND PROMOTION EFFICIENCY IN 
INCREASING THE ENVIRONMENTAL NGOs COMPETITIVENESS. Calitatea, 19(S1), 417-422.

Popescu, R. I., Corbos, R. A., Comănescu, M., \& Bunea, O. I. (2017). Ecological MarketingStrategic Option for Business Development in Bucharest. ECONOMIC COMPUTATION AND ECONOMIC CYBERNETICS STUDIES AND RESEARCH, 51(2), 67-83.

Porter, M. E. (1985). Technology and competitive advantage. Journal of business strategy, $5(3), 60-78$.

Razali, N.M. \& Wah, Y.B. (2011). Power comparisons of Shapiro-Wilk, Kolmogorov-Smirnov, Lilliefors and Anderson-Darling tests. Journal of Statistical Modeling and Analytics, 2(1), 21-33.

Romanian National Institute of Statistics (2018). Research-Development and Innovation. Retrieved December 10, 2018, from http://statistici.insse.ro/shop/index.jsp?page=tempo2\&lang=en\&context=37.

Schmider, E., Ziegler, M., Danay, E., Beyer, L., \& Bühner, M. (2010). Is it really robust? Methodology.

Shapiro, S.S. \& Wilk, M.B. (1965). An Analysis of Variance Test for Normality. Biometrika, 52(3/4), 591-611.

Shieh, G. (2018). Sample size determination for examining interaction effects in factorial designs under variance heterogeneity. Psychological methods, 23(1), 113.

Singh, A. S., \& Masuku, M. B. (2014). Sampling techniques \& determination of sample size in applied statistics research: An overview. International Journal of Economics, Commerce and Management, 2(11), 1-22.

Tidd, J., \& Bessant, J. (2018). Innovation Management Challenges: From fads to fundamentals. International Journal of Innovation Management, 22(05), 1840007.

Trott, P. (2008). Innovation management and new product development. Pearson education.

Ulusoy, G., Kılıç, K., Günday, G., \& Alpkan, L. (2010). Innovation determinants in manufacturing firms.

Vakhitova, G., \& Pavlenko, T. (2010). Innovation and productivity: A firm level study of Ukrainian manufacturing sector. Discussion Papers, 27.

Weinberg, J. M., \& Kleinman, K. P. (2003). Good study design and analysis plans as features of ethical research with humans. IRB: Ethics \& Human Research, 25(5), 11-14.

Zehir, C., Can, E., \& Karaboga, T. (2015). Linking entrepreneurial orientation to firm performance: the role of differentiation strategy and innovation performance. Procedia-Social and Behavioral Sciences, 210, 358-367.

Zemplinerová, A., \& Hromádková, E. (2012). Determinants of firm's innovation. Prague Economic Papers, 21(4), 487-503. 